\title{
Detection of glutamate synthase (GOGAT) activity in phytoplankton: evaluation of cofactors and assay optimization
}

\author{
John R. Clayton, Jr. ${ }^{1,2, *}$ \& Saiyed I. Ahmed ${ }^{1}$ \\ ${ }^{1}$ School of Oceanography, WB-10, and ${ }^{2}$ School of Fisheries, WH-10, \\ University of Washington, Seattle, Washington 98195, USA
}

\begin{abstract}
Relative in vitro activity levels for the enzyme glutamate synthase (GOGAT) with the cofactors NADH, NADPH and reduced ferredoxin were determined with a ${ }^{14} \mathrm{C}$ method in 6 species of phytoplankton from 3 taxonomic classes. The NADH form of the enzyme was the dominant isozyme in all of the marine and estuarine species, while the ferredoxin form was dominant in the 1 fresh-water species tested. Significant amounts of an NADPH specific GOGAT were not detected in any of the organisms. A sensitive fluorometric assay for in vitro measurements was subsequently utilized to determine the substrate kinetics, $\mathrm{pH}$ optimum and temperature-dependent activation energy for NADH-GOGAT in the diatom Skeletonema costatum. Good agreement was obtained with the optimal in vitro assay conditions for activity measurements of NADH-GOGAT on a common phytoplankton extract with the ${ }^{14} \mathrm{C}$ and fluorometric assay methods. The sensitivities of the 2 assays (i.e. fluorometric and ${ }^{14} \mathrm{C}$ ) make them suitable for application in studies of nitrogen assimilation and phytoplankton growth rate dynamics in aquatic ecosystems.
\end{abstract}

\section{INTRODUCTION}

Nitrogen is an essential nutrient for the growth of marine phytoplankton. Forms of extracellular combined inorganic nitrogen that can be utilized by eukaryotic phytoplankton include nitrate $\left(\mathrm{NO}_{3}^{-}\right)$, nitrite $\left(\mathrm{NO}_{2}^{-}\right)$and ammonium $\left(\mathrm{NH}_{4}^{+}\right)$. With $\mathrm{NO}_{3}^{-}$and $\mathrm{NO}_{2}^{-}$, these forms of nitrogen are first reduced intracellularly to $\mathrm{NH}_{4}^{+}$by the actions of the enzymes nitrate reductase and nitrite reductase, respectively. The $\mathrm{NH}_{4}^{+}$derived from either $\mathrm{NO}_{3}^{-}$and/or $\mathrm{NO}_{2}^{-}$reduction or direct uptake from the extracellular medium is then assimilated into amino acids. The specific pathway for this latter assimilation step has been the subject of considerable speculation, with the current consensus favoring a coupled enzymatic reaction involving glutamine synthetase (GS) and glutamate synthase (GOGAT) (Morris 1974, Ahmed et al. 1977. Miflin \& Lea 1980, Syrett 1981, Wheeler 1983, Falkowski 1983, Bressler \& Ahmed 1984).

\footnotetext{
- Present address: Science Applications International Corporation, 476 Prospect St., La Jolla, California 92037, USA
}

Both the phylogenetic occurrence of GS and sensitive assay methods for its detection have been documented for a variety of phytoplankton species (Bressler \& Ahmed 1984, Clayton \& Ahmed unpubl.). However, only very limited information exists regarding the exact nature and extent of the GOGAT reaction in marine phytoplankton. The GOGAT reaction can be briefly summarized in the following manner:

glutamine + 2-oxoglutarate $+\mathrm{NAD}(\mathrm{P}) \mathrm{H}$ [or $\mathrm{Fd}_{\text {red }}$ ] $\stackrel{\text { GOGAT }}{\longrightarrow} 2$ (glutamate) $+\mathrm{NAD}(\mathrm{P})^{+}\left[\mathrm{or} \mathrm{Fd}_{\mathrm{ox}}\right]$

with the essential electron donor component(s) being satisfied by reduced forms of either nicotinamide adenine dinucleotide (NADH), nicotinamide adenine dinucleotide phosphate (NADPH) or ferredoxin $\left(\mathrm{Fd}_{\mathrm{red}}\right)$. This paper presents information on the following topics regarding in vitro GOGAT activity measurements in phytoplankton samples: (1) the relative activity levels of GOGAT with the 3 separate electron donor molecules ( $\mathrm{NADH}, \mathrm{NADPH}$ and $\mathrm{Fd}_{\text {red }}$ ) in a variety of phytoplankton species, (2) a sensitive fluorometric assay technique that can be applied to in vitro mea- 
surements of NADH-GOGAT (and/or NADPHGOGAT), and (3) substrate kinetic studies for in vitro NADH-GOGAT activities in the marine diatom Skeletonema costatum.

\section{MATERIALS AND METHODS}

Chemicals. All inorganic chemicals were reagent grade quality. The following chemicals were obtained from Sigma Chemical Co. (St. Louis, Missouri, USA): glutamine, 2-oxoglutarate, NADH, NAD ${ }^{+}, \mathrm{NADPH}$, ferredoxin from spinach (Type III), ferredoxin from the red marine alga Porphyra umbilicalis (Type VI), ferredoxin from the bacterium Clostridium pasteurianum (Type V), 2-amino-2-hydroxymethyl-1,3propanediol (Trizma buffer), beta-mercaptoethanol, polyvinylpyrrolidone (PVP), aminooxyacetic acid (AOA), (ethylenedinitrilo)tetraacetic acid (EDTA) and methyl viologen. New England Nuclear was the source for the following: ${ }^{14} \mathrm{C}$-glutamine $\left(\mathrm{NEC}-451, \mathrm{~L}-\left[{ }^{14} \mathrm{C}(\mathrm{U})\right]-\right.$ glutamine, $272.0 \mathrm{mCi} \mathrm{mmol}^{-1}$ ) and ${ }^{14} \mathrm{C}$-glutamate (NEC-290E, L- $\left[{ }^{14} \mathrm{C}(\mathrm{U})\right]-$ glutamic acid, $292.0 \mathrm{mCi}$ $\mathrm{mmol}^{-1}$ ). AG1-X8 (acetate form) analytical grade anion exchange resin (200 to 400 mesh) was purchased from Bio-Rad Laboratories.

Algal cultures. Axenic cultures of the following marine and fresh water species from 3 algal classes were used during various phases of the studies reported in this paper:

Bacillariophyceae: Skeletonema costatum (Grev.) Cleve (R.R.L. Guillard 1956, Milford Harbor, Connecticut, USA),

Thalassiosira pseudonana Hasle \& Heimdal (R.R.L. Guillard, Great South Bay, New York, USA);

Chlorophyceae: Chlamydomonas reinhardtii (UTEX clone 90),

Chlamydomonas sp. (R.R.L. Guillard 1957, Milford

Harbor, Connecticut, USA, clone D),

Dunaliella euchlora (F. Taub);

Prymnesiophyceae: Isochrysis galbana Parke (M.

Parke, Plymouth, U.K.).

S. Costatum and Chlamydomonas sp. (clone D) were obtained from the Culture Collection of Marine Phytoplankton (CCMP), Bigelow Laboratory for Ocean Sciences, West Boothbay Harbor, Maine (c/o Dr, R. R. L. Guillard). C. reinhardtii was obtained from the Culture Collection of Algae, Department of Botany, The University of Texas at Austin, Austin, Texas (c/o Dr. R. Starr). T. pseudonana, D. euchlora and I. galbana were obtained from the Marine Phytoplankton Culture Collection, School of Oceanography, University of Washington, Seattle, Washington (c/o Ms. B. Booth). C. reinhardtii is a fresh-water form, Chlamydomonas sp. (clone D) is estuarine, and the remaining 4 species are marine.

All marine and estuarine species were maintained as batch cultures in autoclaved natural sea water obtained from a depth of 3 to $10 \mathrm{~m}$ in the main basin of Puget Sound, Washington, USA. Sterile nutrients were added according to concentrations specified in Harrison et al. (1980), with $\mathrm{NO}_{3}^{-}$being the sole nitrogen source, and were always present at non-limiting growth concentrations. Chlamydomonas reinhardtii was maintained in a fresh-water medium identical to that in Thacker \& Syrett (1972), except that soil extract (McLachlan 1973) was added to promote growth. All cultures were maintained in constant temperature water baths at $16.5^{\circ} \mathrm{C}$. Continuous light (i.e. $24 \mathrm{~h} \mathrm{~d}^{-1}$ ) at an intensity of 0.68 to $0.70 \times 10^{16}$ quanta $\mathrm{cm}^{-2} \mathrm{~s}^{-1}$ was provided by cool white fluorescent bulbs through a blue plexiglas sheet (Rohm \& Haas \#2069) to simulate coastal marine waters at a depth of $5 \mathrm{~m}$ (Harrison et al. 1977).

Preparation of whole cell homogenates for enzyme assays. A known volume of a phytoplankton culture solution was vacuum filtered ( $\leq 10 \mathrm{~cm} \mathrm{Hg}$ ) through a precombusted $\left(500^{\circ} \mathrm{C}\right.$ for $\left.24 \mathrm{~h}\right)$ Whatman $934-\mathrm{AH}$ glass fiber filter (42.5 mm diameter). The filter was immediately transferred to an iced Potter Elvehjem tissuehomogenizing tube containing $4.00 \mathrm{ml}$ of GOGAT grinding buffer and homogenized in an ice bath for 2.0 min with a teflon pestle attached to an electric motor. Particular care was taken to avoid 'foaming' of the homogenate during the grinding process. The resulting whole cell homogenate was transferred to an iced graduated glass centrifuge tube and its total volume recorded. In vitro assay measurements were immediately performed with the whole cell homogenate. The amount of total protein from whole cell homogenates that was added to in vitro enzyme assay tubes discussed below never exceeded $530 \mu \mathrm{g}$. The GOGAT grinding buffer was prepared just prior to the homogenization procedure and had the following composition with a $\mathrm{pH}$ of 7.5 ( $\mathrm{pH}$ adjusted with $\mathrm{HCl}$ ): (1) $50 \mathrm{mM}$ Trizma buffer, (2) $12.5 \mathrm{mM}$ beta-mercaptoethanol, (3) $5.00 \mathrm{mM}$ EDTA, and (4) $0.15 \%$ (w/v) PVP.

${ }^{14} \mathrm{C}$ method for in vitro GOGAT activity measurements. This assay is a modification of methods in Prusiner \& Milner (1970) and Cullimore \& Sims (1981a). For an assay, $0.200 \mathrm{ml}$ volumes of the whole cell homogenate were added to each of 6 glass centrifuge tubes containing $0.550 \mathrm{ml}$ of specified reaction substrate mixtures. With the whole cell homogenate additions, 3 of these tubes had the following substrate concentrations: (1) $8.00 \mathrm{mM}$ glutamine (with a known specific activitiy in the region of $60 \mathrm{cpm}\left(10^{-9}\right.$ mole of 
glutamine $)^{-1}$, (2) $5.00 \mathrm{mM}$ 2-oxoglutarate, (3) an electron donor compound at concentrations specified below, and (4) $50 \mathrm{mM}$ Trizma buffer ( $\mathrm{pH}$ adjusted to 7.5 with $\mathrm{HCl}$ ). The remaining 3 tubes had identical substrate compositions, except that 2-oxoglutarate was absent. The tubes without 2-oxoglutarate served as controls for the in vitro assays. For assays performed with NADH or NADPH, concentrations of these electron donor compounds were adjusted to $700 \mu \mathrm{M}$. Prior to their additions to the reaction tubes, parent solutions of NADH or NADPH in $50 \mathrm{mM}$ carbonate buffer $(\mathrm{pH}=$ 10.6) were placed in a boiling water bath for $3.0 \mathrm{~min}$ to insure that any $\mathrm{NAD}^{+}$or $\mathrm{NADP}^{+}$present would be destroyed (Lowry \& Passonneau 1972). Assay tubes containing ferredoxin as the electron donor compound had $0.05 \mathrm{mg} F d$ in addition to $25.4 \mathrm{mM} \mathrm{NaHCO} 3,12.3$ $\mathrm{mM} \mathrm{Na}_{2} \mathrm{~S}_{2} \mathrm{O}_{4}$ and $6.66 \mathrm{mM}$ aminooxyacetate (AOA). $\mathrm{NaHCO}_{3}$ and $\mathrm{Na}_{2} \mathrm{~S}_{2} \mathrm{O}_{4}$ served to maintain the ferredoxin in a reduced state, and AOA was added to inhibit aminotransferases that might be present in the whole cell homogenates of phytoplankton samples.

The fully constituted tubes containing whole cell homogenate extracts and reaction substrates were incubated at $25^{\circ} \mathrm{C}$ for $60.0 \mathrm{~min}$. The reaction was then terminated by addition of perchloric acid to a concentration of $0.40 \mathrm{M}$. Following centrifugation to remove cellular and filter debris, the $\mathrm{pH}$ of the supernatant was adjusted to 7 with $\mathrm{NaOH}$. The supernatant was then loaded onto an ion-exchange column $(5.0 \mathrm{~mm}$ diameter by $35 \mathrm{~mm}$ high) containing AG1-X8 (acetate) resin and eluted with $3.0 \mathrm{ml}$ of $50 \mathrm{mM}$ acetic acid and $0.5 \mathrm{ml}$ of $500 \mathrm{mM} \mathrm{HCl}$. After discarding these eluants, the column was eluted with an additional $3.0 \mathrm{ml}$ of $500 \mathrm{mM} \mathrm{HCl}$. The latter eluant was collected in a $20 \mathrm{ml}$ scintillation vial that received $10.0 \mathrm{ml}$ of the liquid scintillation cocktail Tritosol (Fricke 1975). The ${ }^{14} \mathrm{C}$ content of this solution (representing ${ }^{14} \mathrm{C}$-glutamate) was measured with a Packard Tri-Carb liquid scintillation spectrometer.

To eliminate contributions of ${ }^{14} \mathrm{C}$-glutamate formed by background metabolic reactions, GOGAT activities were calculated from the difference between ${ }^{14} \mathrm{C}$ glutamate quantities in the plus and minus 2-oxogluta rate reaction tubes. To calibrate the quantities of ${ }^{14} \mathrm{C}$ glutamate formed during assays, reaction substrate tubes containing ${ }^{14} \mathrm{C}$-glutamate standards without phytoplankton extracts were processed concurrently through the entire procedure. For all ${ }^{14} \mathrm{C}$ assays reported in this paper the ratios of total substrate available to substrate consumed in reaction tubes for glutamine, 2-oxoglutarate and $\mathrm{NADH}$ were always greater than 30,30 and 4.2, respectively.

Evaluation of the occurrence of NADH-, NADPHand reduced ferredoxin-linked forms of GOGAT in phytoplankton. To evaluate the identity of natural electron donor forms participating in the GOGAT reactions in eukaryotic phytoplankton, a series of experiments were performed to determine in vitro enzyme activities using NADH, NADPH and reduced ferredoxin $\left(\mathrm{Fd}_{\text {red }}\right)$ in extracts from exponentially growing $\left(\mathrm{NO}_{3}^{-}\right.$sufficient) cultures of the 6 species of phytoplankton listed earlier. In one of the experiments the ferredoxin-linked form of the enzyme was measured with ferredoxins from 3 separate sources: (1) spinach, (2) the red marine alga Porphyra umbilicalis and (3) the bacterium Clostridium pasteurianum.

Filter samples for enzyme measurements were analysed for GOGAT activities by means of the ${ }^{14} \mathrm{C}$ assay method. To insure that reducing conditions existed in the Fd tests, separate reaction tubes were periodically included in the assay procedure that contained not only the complete Fd substrate reaction mixture but also $0.4 \mu$ moles of methyl viologen. In every experimental assay containing methyl viologen, the tubes maintained a blue (i.e. reduced) color throughout the $25^{\circ} \mathrm{C}$ incubation period. Tests were not run with methyl viologen added to tubes containing phytoplankton extracts, since reduced methyl viologen can act as an electron donor for the GOGAT reaction (Lea \& Miflin 1974, 1975, Cullimore \& Sims 1981a, Marquez et al. 1984).

Fluorometric method for in vitro GOGAT activity measurements. This assay involves measurements of the fluorometric derivatives of $\mathrm{NAD}^{+}$(or $\mathrm{NADP}^{+}$) produced in the GOGAT reaction. As such, the assay is applicable to only NADH- (or NADPH-)linked forms of the enzyme. The fluorometric derivation process is presented in Lowry \& Passonneau (1972), and has been successfully applied to measurements of the enzymes NADPH-glutamate dehydrogenase (GDH) and NADHGDH in phytoplankton samples (Ahmed et al. 1977). Since NADPH-GOGAT was not detected by the ${ }^{14} \mathrm{C}$ method in any of the phytoplankton samples analysed for this paper (see 'Results'), the fluorometric assay method was only applied to NADH-GOGAT activity measurements.

The incubation portion of this assay was similar to that of the ${ }^{14} \mathrm{C}$ method. For a given phytoplankton sample, $0.200 \mathrm{ml}$ volumes of whole cell homogenate were added to each of 6 tubes containing $0.550 \mathrm{ml}$ of reaction substrate mixture. Three of the fully constituted tubes had substrate mixtures in the following concentrations: (1) $8.00 \mathrm{mM}$ glutamine, (2) $5.00 \mathrm{mM} 2$ oxoglutarate, (3) $700 \mu \mathrm{M}$ NADH, and (4) $50 \mathrm{mM}$ Trizma buffer ( $\mathrm{pH}$ adjusted to 7.5 with $\mathrm{HCl}$ ). The remaining 3 tubes had identical compositions, except that glutamine was absent. The parent NADH substrate solution was prepared in an identical manner to that in the ${ }^{14} \mathrm{C}$ method. Incubations were conducted at $25^{\circ} \mathrm{C}$ for $30.0 \mathrm{~min}$. Reactions were terminated by adding 
$0.300 \mathrm{ml}$ of $3 \mathrm{M} \mathrm{HCl}$ to each tube, which also destroyed all remaining $\mathrm{NADH}$. Following centrifugation to remove cellular and filter debris, the $\mathrm{NAD}^{+}$in the supernatant was converted to a fluorometrically active derivative by adding $1.00 \mathrm{ml}$ of $0.3 \%(\mathrm{v} / \mathrm{v}) \mathrm{H}_{2} \mathrm{O}_{2}$ in $12.5 \mathrm{M} \mathrm{NaOH}$ and incubating at $60^{\circ} \mathrm{C}$ for $10 \mathrm{~min}$. The fluorometric derivation procedure and all subsequent sample treatment steps were performed in a darkened room to minimize light-mediated breakdown of the fluorescent product. Fluorescence measurements were made with a Turner Model 430 spectrofluorometer at excititation and emission wavelengths of 360 and $460 \mathrm{~nm}$, respectively.

To eliminate contributions of $\mathrm{NAD}^{+}$formation from background metabolic reactions, NADH-GOGAT activities were calculated from the difference between $\mathrm{NAD}^{+}$quantities generated in the plus and minus glutamine reaction tubes. To calibrate the quantities of $\mathrm{NAD}^{+}$formed during an assay, concurrent reaction substrate tubes containing $\mathrm{NAD}^{+}$standards without phytoplankton extract were processed through the entire procedure. For all fluorometric assays reported in this paper the ratios of total substrate available to substrate consumed in reaction tubes for glutamine, 2oxoglutarate and NADH were always greater than 55 . 35 and 5, respectively.

Protein measurements in phytoplankton filter samples. When a phytoplankton filter sample was collected for GOGAT activity measurements, a second filter was always collected for protein determinations and stored at liquid nitrogen temperature $\left(-196^{\circ} \mathrm{C}\right)$ until the analyses could be performed. The method for protein measurements was similar to that in Peterson (1977).

\section{RESULTS}

\section{In vitro GOGAT activities}

The ${ }^{14} \mathrm{C}$ method was used to obtain in vitro GOGAT activities in phytoplankton cultures with either $\mathrm{NADH}$, NADPH or reduced ferredoxin as the electron donor compound. Six species of phytoplankton were tested, and all cultures were in an exponential state of growth ( $\mathrm{NO}_{3}^{-}$-sufficient) at the times of the assays. The results of the GOGAT activity measurements are summarized in Table 1. From the information in the table the following points can be made: (1) the highest activities were observed with $\mathrm{NADH}$ in all of the marine and estuarine species; (2) no significant activity was detected for NADPH-GOGAT in any of the test organisms; (3) ferredoxin-GOGAT generally exhibited low or undetectable activity levels except in the freshwater species Chlamydomonas reinhardtii; and (4) the use of ferredoxins from different sources could result in different enzyme activity levels. The predominance of $\mathrm{NADH}$-GOGAT in the marine organisms is further emphasized by the ratios of NADH-GOGAT to Fd-

Table 1. Summary of GOGAT activity measurements using different electron donor compounds in 6 species of phytoplankton. Values for enzyme activities are means with SD below in parentheses $(n=3)$. All activities are in units of $10^{-9}$ moles of glutamine consumed $\left(10^{-3} \mathrm{~g} \text { protein } \mathrm{min}\right)^{-1}$. Ferredoxin (Fd) types are the following: Spin. Fd is from spinach; Porph.Fd is from the marine red algae Porphyra umbilicalis; Clost. Fd is from the bacterium Clostridium pasteurianum

\begin{tabular}{|c|c|c|c|c|c|c|c|}
\hline \multirow[t]{2}{*}{ Class } & \multirow[t]{2}{*}{ Species } & \multicolumn{6}{|c|}{ GOGAT activity } \\
\hline & & NADH & NADPH & Spin. Fd & Porph. Fd & Clost. Fd & $\mathrm{NADH} / \mathrm{Fd}$ \\
\hline \multirow[t]{4}{*}{ Bacillariophyceae } & Skeletonema costatum \# 1 & $\begin{array}{c}6.33 \\
(0.1)\end{array}$ & ND & $\begin{array}{c}0.43 \\
(0.15)\end{array}$ & $\begin{array}{c}0.51 \\
(0.15)\end{array}$ & $\begin{array}{c}0.54 \\
(0.22)\end{array}$ & $\begin{array}{c}11.85- \\
14.59\end{array}$ \\
\hline & $\# 2$ & $\begin{array}{l}4.15 \\
(0.45)\end{array}$ & $\begin{array}{c}0.50 \\
(0.45)\end{array}$ & $\begin{array}{c}0.21 \\
(0.21)\end{array}$ & ND & ND & 20.18 \\
\hline & $\# 3$ & $\begin{array}{l}10.96 \\
(1.30)\end{array}$ & $\begin{array}{c}0.84 \\
(0.83)\end{array}$ & $\begin{array}{c}0.43 \\
(0.61)\end{array}$ & ND & ND & 25.40 \\
\hline & Thalassiosira pseudonana & $\begin{array}{c}4.35 \\
(1.29)\end{array}$ & 0 & 0 & ND & ND & NA \\
\hline \multirow[t]{3}{*}{ Chlorophyceae } & Chlamydomonas reinhardtii & $\begin{array}{c}0.78 \\
(0.49)\end{array}$ & $\mathrm{ND}$ & $\begin{array}{c}1.14 \\
(0.91)\end{array}$ & $\begin{array}{c}2.02 \\
(0.68)\end{array}$ & $\begin{array}{c}2.43 \\
(0.73)\end{array}$ & $\begin{array}{r}0.32- \\
0.68\end{array}$ \\
\hline & Chamydomonas sp. (clone D) & $\begin{array}{c}4.44 \\
(0.46)\end{array}$ & $\begin{array}{c}0.52 \\
(1.98)\end{array}$ & $\begin{array}{c}0.35 \\
(1.29)\end{array}$ & ND & ND & 12.68 \\
\hline & Dunaliella euchlora & $\begin{array}{c}0.79 \\
(0.37)\end{array}$ & $\begin{array}{c}0.57 \\
(0.94)\end{array}$ & 0 & ND & ND & NA \\
\hline Prymnesiophyceae & Isochrysis galbana & $\begin{array}{l}14.75 \\
(1.06)\end{array}$ & 0 & 0 & ND & ND & NA \\
\hline
\end{tabular}


GOGAT in the last column of the table. Based on the general predominance of NADH-GOGAT in the table, subsequent efforts to evaluate reaction substrate kinetics were performed only for the $\mathrm{NADH}$ form of the enzyme.

\section{Comparison of fluorometric and ${ }^{14} \mathrm{C}$ assays and the effect of PVP on NADH-GOGAT activity recoveries}

The NADH form of GOGAT is known to be a particularly unstable form of the enzyme (Cullimore \& Sims 1981a, Marquez et al. 1984). This fact may be partly responsible for the limited amount of information available in the plant literature regarding the occurrence of NADH-GOGAT. Cullimore \& Sims (1981a) reported that NADH-GOGAT could be partially stabilized by adding mercaptoethanol and high levels of sucrose to enzyme extracts and purging buffers with $\mathrm{N}_{2}$ gas. Although mercaptoethanol was included in the grinding buffer and substrate reaction mixtures for the studies in this paper, the effects of sucrose additions and/or buffer purging with $\mathrm{N}_{2}$ were not tested. However, Rhodes (1977) stated that additions of certain polymeric agents can also lead to substantial stabilization of enzymes in extracts from plant tissues. Based on this information and the fact that the polymeric agent PVP was used successfully in measurements of GDH activities in phytoplankton extracts (Ahmed et al. 1977), the effect of PVP upon NADH-GOGAT activities in phytoplankton samples was evaluated.

Six filter samples were collected from an exponentially growing ( $\mathrm{NO}_{3}^{-}$-sufficient) culture of Skeletonema costatum. The whole cell homogenates from these samples were analysed for NADH-GOGAT activities by both the fluorometric and ${ }^{14} \mathrm{C}$ methods. Three of the 6 filters were prepared with a GOGAT grinding buffer containing PVP, while homogenates for the remaining 3 filters were prepared with an

Table 2. NADH-GOGAT in Skeletonema costatum: comparison of fluorometric and ${ }^{14} \mathrm{C}$ assays and the effect of PVP on in vitro activity recovery. Values for enzyme activities are means with SD in parentheses $(n=3)$; activity units are $10^{-9}$ moles $\left(10^{-3} \text { gram protein min }\right)^{-1}$ with moles $=\mathrm{NAD}^{+}$produced for fluorometric assay and glutamine consumed for ${ }^{14} \mathrm{C}$ assay

\begin{tabular}{|lccc|}
\hline \multirow{2}{*}{ Grinding buffer } & \multicolumn{3}{c|}{ NADH-GOGAT activity } \\
& Fluor & ${ }^{14} \mathrm{C}$ & Fluor $/{ }^{14} \mathrm{C}$ \\
\hline Minus PVP & 1.52 & 4.71 & 0.32 \\
Plus PVP & $( \pm 0.61)$ & $( \pm 1.64)$ & \\
& 6.97 & 6.60 & 1.06 \\
Minus PVP/Plus PVP & 0.22 & 0.72 & \\
\hline
\end{tabular}

equivalent grinding buffer that lacked PVP. The results of the in vitro enzyme activities for the 6 whole cell homogenates are summarized in Table 2. Inclusion of PVP in the grinding buffer enhanced recoveries of NADH-GOGAT activities in both the fluorometric and ${ }^{14} \mathrm{C}$ assay methods, although the trend was more pronounced in the fluorometric assay. The reason for the more dramatic effects of PVP in the fluorometric assay is not clear, although PVP may not only enhance the stability of the enzyme but also contribute to greater recoveries of $\mathrm{NAD}^{+}$product in the fluorometric assay. From the information in Table 2 it should also be noted that the 2 assay methods gave remarkably similar results for whole cell homogenates prepared with the grinding buffer containing PVP.

\section{NADH-GOGAT activity as a function of $\mathrm{pH}$ and temperature}

For the $\mathrm{pH}$ studies, identical reaction substrate mixtures were prepared with $\mathrm{pH}$ values varying from 6.9 to 9.2 ( $\mathrm{pH}$ adjusted with $\mathrm{HCl}$ and $\mathrm{NaOH}$ ). All assays were performed with Trizma buffer in the reaction mixture since Trizma is reported to be effective from $\mathrm{pH} 7.1$ to 8.9 (Dawson et al. 1969). Enzyme measurements were performed with the fluorometric assay method for a common whole cell homogenate from an exponentially growing ( $\mathrm{NO}_{3}^{-}$-sufficient) culture of Skeletonema costatum. Maximum rates for in vitro NADH-GOGAT activities were observed in the $\mathrm{pH}$ range of 7.5 to 8.0 .

In assay temperature studies, NADH-GOGAT activities were measured by the fluorometric method on a whole cell homogenate from an exponentially growing ( $\mathrm{NO}_{3}^{-}$-sufficient) culture of Skeletonema costatum at assay temperatures from 0.4 to $45.5^{\circ} \mathrm{C}$. The activity increased to a maximum at $25^{\circ} \mathrm{C}$, and declined at higher temperatures. An Arrhenius plot (Segel 1976) of the data yielded an apparent activation energy $\left(E_{a}\right)$ for NADH-GOGAT of $8300 \mathrm{cal} \mathrm{mole}{ }^{-1}$.

\section{NADH-GOGAT activity as a function of reaction sub- strate concentrations}

Studies were performed to measure the reaction substrate kinetics for glutamine, 2-oxoglutarate and $\mathrm{NADH}$ in $\mathrm{NO}_{3}^{-}$-sufficient batch cultures of Skeletonema costatum. All assay tubes contained varying concentrations for only 1 substrate, with concentrations for the remaining 2 substrates being equivalent to those specified in the appropriate 'Materials and Methods' sections of this paper. These studies were performed with 2 separate phytoplankton extracts: once with the fluorometric assay method and once with 
Table 3. Apparent $\mathrm{K}_{\mathrm{m}}\left(\mathrm{K}_{\mathrm{m}}{ }^{\mathrm{app}}\right)$ values for NADH-GOGAT in eukaryotic phytoplankton. $\mathrm{K}_{\mathrm{m}}{ }^{a p p}$ is the substrate concentration at which the enzyme activity level is $50 \%$ of its maximum value

\begin{tabular}{|lcrrr|}
\hline Species & Glutamine & $\begin{array}{c}\mathrm{K}_{\mathrm{m}}{ }^{a p p}(\mu \mathrm{M}) \\
\text { 2-oxoglutarate }\end{array}$ & NADH & Source \\
\hline Skeletonema costatum Fluor. assay & 309 & 51 & 54 & This study \\
Skeletonema costatum ${ }^{14}$ C assay & 1000 & 406 & 315 & This study \\
Chlamydomonas reinhardtii & 900 & 7 & 13 & Cullimore \& Sims (1981a) \\
Chlymydomonas reinhardtii & 600 & 18 & 8 & Marquez et al. (1984) \\
Euglena gracilis & 300 & 15 & 20 & Miyatake \& Kitaoka (1981) \\
\hline
\end{tabular}

the ${ }^{14} \mathrm{C}$ assay method. Apparent $\mathrm{K}_{\mathrm{m}}$ values for each substrate were calculated by Hanes-Woolf plots (Segel 1976) and are summarized in Table 3 along with equivalent values determined by other investigators for eukaryotic phytoplankton. The $\mathrm{K}_{\mathrm{m}}^{\mathrm{app}}$ values determined by the fluorometric method for $S$. costatum in this study are comparable to those reported by other investigators in the table for other species. The higher $\mathrm{K}_{\mathrm{m}}^{\mathrm{app}}$ values obtained by the ${ }^{14} \mathrm{C}$ method for $S$. costatum do not appear to be related to any substrate limitation, since the initial amounts of all substrates in reaction tubes always substantially exceeded the calculated amounts of the substrates consumed in the reaction. Consequently, the different values obtained by the fluorometric and ${ }^{14} \mathrm{C}$ methods for $S$. costatum were due to some as yet unexplained phenomenon. However, the differences may reflect slightly variant prehistories for the experimental cultures in the 2 tests, although a concerted effort was made to produce 'equivalent' experimental batch cultures of $S$. costatum for the studies in Table 3 . Other studies in this laboratory have shown that NADH-GOGAT activities in $S$. costatum can be dramatically affected by phytoplankton culture conditions such as the previous availability of extracellular nutrient nitrogen (Clayton, Ahmed \& Thoresen unpubl.). Pending further resolution of the reasons for the detection of the high $\mathrm{K}_{\mathrm{m}}^{\mathrm{app}}$ values for 2oxoglutarate and $\mathrm{NADH}$ by the ${ }^{14} \mathrm{C}$ assay technique, the fluorometric assay can serve as a highly sensitive and rapid technique for the detection of pyridine nuclcotide specific GOGAT in marine phytoplankton.

\section{DISCUSSION}

The apparent dominance of NADH-GOGAT in the marine phytoplankton species evaluated in this paper (Table 1) was somewhat unexpected since pyridine nucleotide (i.e. NADH- and NADPH-)GOGATs have not been reported in chlorophyll-containing cells from higher plants (Lea \& Miflin 1974, Rhodes et al. 1976, Stewart \& Rhodes 1978) or in the green alga Chlorella fusca (Lea \& Miflin 1975). Studies of the subcellular localization of the enzyme in angiosperms indicate that Fd-GOGAT is found in chloroplasts where photosynthetically reduced ferredoxin occurs (Rathnan \& Edwards 1976, Harel et al. 1977, Wallsgrove et al. 1979). Therefore, it would seem reasonable to assume that the chlorophyll-containing, photosynthetically active cells of eukaryotic algae should exhibit substantial activities for Fd-GOGAT. Since substrate reaction tubes containing methyl viologen indicated that reducing conditions existed during assays, the low or undetectable levels of Fd-GOGAT did not appear to be the result of non-reducing conditions in the reaction tubes. Furthermore, the enzyme measurements in Table 1 for Chlamydomonas reinhardtii and Skeletonema costatum (\#1) were run at the same time, with $C$. reinhardtii actually demonstrating higher activities for the Fd form of GOGAT (implying that the Fd substrate was in an enzymatically active state). Selective destruction of the Fd-GOGAT (as opposed to NADHGOGAT) during sample extraction and/or incubation steps also seems unlikely, since the NADH form of the enzyme has been reported to be considerably less stable than the Fd form of the enzyme (Cullimore \& Sims 1981a, Marquez et al. 1984). Consequently, the dominance of NADH-GOGAT during $\mathrm{NO}_{3}^{-}$assimilation in the species of marine phytoplankton tested could not be explained by an obvious artifact in the assay procedure itself. This implies that the NADH form of the enzyme may be extremely important to the overall assimilation of extracellular $\mathrm{NO}_{3}^{-}$, particularly in marine species of phytoplankton.

Information is very limited in the published literature regarding reported detection of NADH-GOGAT in species of eukaryotic green algae. NADH-GOGAT has been found in Chlamydomonas reinhardtii by Cullimore \& Sims (1981a,b) and Marquez et al. (1984) and in Euglena gracilis by Miyatake \& Kitaoka (1981). Since Cullimore \& Sims (1981a) found that methyl viologen-GOGAT and NADH-GOGAT in C. reinhardtii appeared to be the same isozyme, the reported in vitro GOGAT activities mediated by the artificial electron donors methyl viologen in Caulerpa simpliciuscula (McKenzie et al. 1979) and benzyl viologen in Platy- 
monas striata (Edge \& Ricketts 1978) may be indicative of NADH-GOGAT in these algal species. However, Marquez et al. (1984) found that methyl viologenGOGAT could correspond to both the NADH and ferredoxin forms of the enzyme.

The detection and assay methods reported for in vitro GOGAT measurements in this paper serves as essential information to a broader study involving a detailed assessment of the effects of extracellular nitrogen availability on nitrogen metabolism in phytoplankton. In this context, the consensus from studies by other investigators indicates that the major pathways for the initial assimilation of $\mathrm{NH}_{4}^{+}$into amino acids involve either (1) the glutamate dehydrogenase (GDH) enzyme and/or (2) the coupled reactions of glutamine synthetase and glutamate synthase (GS/GOGAT) (Morris 1974, Miflin \& Lea 1980, Syrett 1981, Wheeler 1983, Falkowski 1983). In the studies of Ahmed et al. (1977) all of the marine phytoplankton species examined exhibited high apparent $\mathrm{K}_{\mathrm{m}}$ values for $\mathrm{NH}_{4}^{+}$ (ca 4 to $10 \mathrm{mM}$ range) in the $\mathrm{GDH}$ reaction. In subsequent studies with the diatom Skeletonema costatum Dortch et al. (1979) concluded that GDH could account for less than $5 \%$ of the $\mathrm{NH}_{4}^{+}$uptake and assimilation rates in cells. An ensuing examination of 13 marine phytoplankton species comprising 6 algal classes revealed the presence of the GS enzyme with much greater affinities for $\mathrm{NH}_{4}^{+}$(ca 2 to $8 \mu \mathrm{M}$ ) (Bressler \& Ahmed 1984). Therefore, the occurrence of a highly efficient $\mathrm{NH}_{4}^{+}$assimilating enzyme system (i.e. the GS/ GOGAT pathway) should be particularly important to phytoplankton living in marine environments frequently characterized by extremely low extracellular concentrations of nutrient nitrogen. It follows that the development and optimization of a sensitive in vitro assay for the GOGAT enzyne, together with a sensitive GS enzyme assay (Bressler \& Ahmed 1984, Clayton \& Ahmed unpubl.), should facilitate efforts to unravel the intricacies of nitrogen nutrition and physiological control mechanisms operating in aquatic ecosystems.

Acknowledgements. This research was supported by NSF Grants OCE 79-1959-1 and OCE 81-17937-2 awarded to Dr. S. I. Ahmed. This work was performed in partial fulfillment of the $\mathrm{Ph}$. D. requirements for J. R. C. We gratefully acknowledge Steven $\mathrm{S}$. Thoresen for his constant assistance throughout these studies and Jim Postel and Will Peterson for their assistance in the liquid scintillation counting of ${ }^{14} \mathrm{C}$ samples. Contribution No. 1641 from the School of Oceanography, University of Washington.

\section{LITERATURE CITED}

Ahmed, S. I., Kenner, R. A., Packard, T. T. (1977). A comparative study of the glutamate dehydrogenase activity in several species of marine phytoplankton. Mar, Biol. 39: 93-101

Bressler, S. L., Ahmed, S. I. (1984). Detection of glutamine synthetase activity in marine phytoplankton: optimization of the biosynthetic assay. Mar. Ecol. Prog. Ser. 14: 207-217

Cullimore, J. V., Sims, A. P. (1981a). Occurrence of two forms of glutamate synthase in Chlamydomonas reinhardii. Phytochemistry $20: 597-600$

Cullimore, J. V., Sims, A. P. (1981b). Pathway of ammonia assimilation in illuminated and darkened Chlamydomonas reinhardii. Phytochemistry 20: 933-940

Dawson, R. M. C., Elliott, D. C., Elliott, W. H., Jones, K. M. (1969). Data for biochemical research. Oxford University Press, Oxford

Dortch, Q., Ahmed, S. I., Packard, T. T (1979). Nitrate reductase and glutamate dehydrogenase activities in Skeletonema costatum as measures of nitrogen assimilation rates. J. Plankton Res. 1: 169-186

Edge, P. A., Ricketts, T R. (1978). Studies on ammoniumassimilating enzymes of Platymonas striata Butcher (Prasinophyceae). Planta 138: 123-125

Falkowski, P. G. (1983). Enzymology of nitrogen assimilation. In: Carpenter, E. J., Capone, D. G. (ed.) Nitrogen in the marine environment. Academic Press, New York, p. $839-868$

Fricke, U. (1975). Tritosol: A new scintillation cocktail based on Triton X-100. Analyt. Biochem. 63: 555-558

Harel, E., Lea, P. J., Miflin, B. J. (1977). The localization of enzymes of nitrogen assimilation in maize leaves and their activities during greening. Planta 134: 195-200

Harrison, P. J., Conway, H. L., Holmes, R. W., Davis, C. O. (1977). Marine diatoms grown in chemostats under silicate or ammonium limitation. III. Cellular chemical composition and morphology of Chaetoceros debilis, Skeletonema costatum, and Thalassiosira gravida. Mar. Biol. 43: 19-31

Harrison, P. J., Waters, R. E., Taylor, F. J. R. (1980). A broad spectrum artificial seawater medium for coastal and open ocean phytoplankton. J. Phycol. 16: 28-35

Lea, P. J., Miflin, B. J. (1974). Alternative route for nitrogen assimilation in higher plants. Nature, Lond. 251: 614-616

Lea, P. J., Miflin, B. J. (1975). The occurrence of glutamate synthase in algae. Biochem. biophys. Res. Commun. 64 : 856-862

Lowry, O. H., Passonneau, J. V. (1972). A flexible system of enzymatic analysis. Academic Press, New York

Marquez, A. J., Galvan, F., Vega, J. M. (1984). Purification and characterization of the NADH-glutamate synthase from Chlamydomonas reinhardii. Plant Sci. Lett. 34: 305-314

McKenzie, G. H., Ch'ng, A. L., Gayler, K. R. (1979). Glutamine synthetase/glutamine:a-ketoglutarate aminotransferase in chloroplasts from the marine alga Caulerpa simpliciuscula. Pl. Physiol 63: 578-582

Mclachlan, J. (1973). Growth media - marine. In: Stein, J. R. (ed.) Handbook of phycological methods. Culture methods and growth measurements. Cambridge Univ. Press, Cambridge, p. 25-51

Miflin, B. J., Lea, P. J. (1980). Ammonia assimilation. In: Miflin, B. J. (ed.) The biochemistry of plants. A comprehensive treatise. Vol. 5. Amino acids and derivatives. Academic Press, New York, p. 169-202

Miyatake, K. Kitaoka, S. (1981). NADH-dependent glutamate synthase in Euglena gracilis z. Agric. Biol. Chem. 45: $1727-1729$

Morris, I. (1974). Nitrogen assimilation and protein synthesis. In: Stewart, W. D. P. (ed.) Algal physiology and 
biochemistry. Univ. of Calif. Press, Berkeley, p. 583-609

Peterson, G. L. (1977). A simplification of the protein assay method of Lowry et al. which is more generally applicable. Analyt. Biochem. 83: 346-356

Prusiner, S., Milner, L. (1970). A rapid radioactive assay for glutamine synthetase, glutaminase, asparagine synthetase and asparaginase. Analyt. Biochem. 37: 429-438

Rathnam, C. K. M., Edwards, G. E. (1976). Distribution of nitrate-assimilating enzymes between mesophyll protoplasts and bundle sheath cells in leaves of three groups of $\mathrm{C}_{4}$ plants. Pl. Physiol. 57: 881-885

Rhodes, D., Rendon, G. A., Stewart, G. R. (1976). The regulation of ammonia assimilating enzymes in Lemna minor. Planta 129: 203-210

Rhodes, M. J. C. (1977). The extraction and purification of enzymes from plant tissues. In: Smith, $H$. (ed.) Regulation of enzyme synthesis and activitiy in higher plants. Academic Press, London, p. 245-269
Segel, I. H. (1976). Biochemical calculations. John Wiley and Sons, Inc., New York

Stewart, G. R., Rhodes, D. (1978). Nitrogen metabolism of halophytes. III. Enzymes of ammonia assimilation. New Phytol. 80: 307-316

Syrett, P. J. (1981). Nitrogen metabolism of microalgae. In: Platt, T. (ed.) Physiological bases of phytoplankton ecology. Can. Bull. Fish. Aquat. Sci. 210: 182-210

Thacker, A., Syrett, P. J. (1972). The assimilation of nitrate and ammonium by Chlamydomonas reinhardi. New Phytol. 71: 423-433

Wallsgrove, R. M., Lea, P. J., Miflin, B. J. (1979). Distribution of the enzymes of nitrogen assimilation within the pea leaf cell. Pl. Physiol. 63: 232-236

Wheeler, P. A. (1983). Phytoplankton nitrogen metabolism. In: Carpenter, E. J., Capone, D. G. (ed.) Nitrogen in the marine environment. Academic Press, New York, p. 309-346 